Article

\title{
Digital Competences of Polish and Slovak Students-Comparative Analysis in the Light of Empirical Research
}

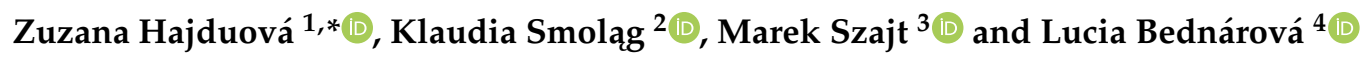 \\ 1 Department of Business Finance, Faculty of Business Management, University of Economics in Bratislava, \\ Dolnozemská Cesta 1, 85235 Bratislava, Slovakia \\ 2 Institute of Information Management Systems, Faculty of Management University of Technology, \\ Dąbrowskiego 69, 42-200 Częstochowa, Poland; klaudia.smolag@wz.pcz.pl \\ 3 Department of Econometrics and Statistics, Faculty of Management University of Technology, \\ Dąbrowskiego 49, 42-200 Częstochowa, Poland; marek.szajł@wz.pcz.pl \\ 4 Faculty of Mining, Ecology, Process Control and Geotechnologies, Technical University of Kosice, Letná 9, \\ 04001 Košice, Slovakia; lucia.bednarova@tuke.sk \\ * Correspondence: zuzana.hajduova@euba.sk
}

Received: 27 August 2020; Accepted: 17 September 2020; Published: 18 September 2020

check for updates

\begin{abstract}
Skills in using information and communication technology solutions in the modern world determine the quality of professional and social life for everyone. The last decade has shown that digital competences are an important group of key competences for every employee and every organization. The purpose of this study is to present results of surveys on digital competences of Polish and Slovak students. Generally, results show that assessment of the level of digital competence of Polish students is not only higher but also less diverse. The rationale for addressing the subject of digital competences is its significance, constant changes resulting from development of ICT and the need to improve quality of life of individuals and organizations in the modern digital world. In this questionnaire, the students were asked to evaluate their level of understanding both existing and non-existing terms from the ICT area. The results have shown that there are significant differences between the questioned groups of students especially in case of IT competences.
\end{abstract}

Keywords: digital competences; information competences; IT competences; qualitative analysis; digital world

\section{Introduction}

Digital competence is an important factor shaping the quality of life of both individual and entire organizations. Their importance is constantly growing, which results from dynamics of development of information and communication technologies (ICT) and progressing digital transformation [1]. Development of ICT transforms/changes business models, the way individuals and organizations operate, and enforces a continuous process of learning new things [2]. Digital competences obviously depend on the age, professional activity or education of a given person [3]. These competences are important because they enable functioning in a world dominated by ICT and are part of lifelong learning process $[4,5]$. It could be assumed that people learning in the digital age who commonly use ICT solutions should naturally shape their digital competences, or at least some groups of these competences. However, current research shows that knowledge and skills play an important role in shaping competences, not only access and daily use [6,7]. The role of higher education in this area should be underlined, because it enables students to be independent in both academic and professional environment [8]. Therefore, development of digital competences, regardless of the level of education 
it takes place, is targeted at the entity of the respective educational impact and corresponding level of digital literacy [9]. Teaching digital competences is a result of a combination of technological knowledge and skills, knowledge of the methodological possibilities offered by technological resources, and approach towards the use of ICT to transform and improve education [10].

The purpose of this study is to characterize digital competences based on the literature on the subject and to present own research on digital competences, which was carried out among Polish and Slovak students. The main research question is: How do Polish and Slovak students perceive their digital competences? Are there significant differences in this regard? The research was conducted using the survey method in the period from October 2018 to December 2018.

Characteristics and attempts to define digital competences and determination of a digitally competent person is not simple and unambiguous [11]. Depending on the measurement method and/or information that we want to acquire, defined competences can be gathered in a different number of groups [12]. In addition, areas of using digital competences are not limited to communication or entertainment, but also to education, work and personal development [13]. Digital competences are one of the priority factors in building the strategy of digital economy and digital society [14].

In the article by Jansen et al. [15] Delphi survey results were presented regarding expert opinion on what it means to be digitally competent today. The article describes and discusses final results of the Delphi study with 95 experts from across Europe and beyond.

The results indicate that digital competences are based on knowledge, skills and attitudes regarding twelve different areas:

1. General knowledge and functional skills

2. Use in everyday life

3. Specialized and advanced competence for work and creative expression

4. Technology mediated communication and collaboration

5. Information processing and management

6. Privacy and security

7. Legal and ethical aspects

8. Balanced attitude towards technology

9. Understanding and awareness of role of ICT in society

10. Learning about and with digital technologies

11. Informed decisions on appropriate digital technologies

12. Seamless use demonstrating

This study gathers opinions of experts, not facts, and in this respect the importance of this study lies not in the structure, but in the breadth and richness of collected ideas. This approach to research is part of a broader process that aims to understand and define more precisely the concept of digital competences from different perspectives.

According to the report Information Society in numbers, the concept of digital competences refers to two groups of competences: IT and information. The first group concerns the use of ICT equipment, software, specialized applications, Internet use and digital content creation, and is largely associated with emerging Global Software Development (GSD) process [16]. In turn, information competences refer to all processes related to information management and are related to: the ability to search and obtain information from various sources, assessment of it (assessing credibility and usefulness) and its use Ministry of Administration and Digital Affairs. Another definition is that digital competences are defined as skills, knowledge and attitudes that enable learners to use digital media to participate, work and solve problems, independently and in collaboration with others in a critical, responsible and creative way [17]. According to the European Parliament and the Council, "Digital Competence involves the confident and critical use of Information Society Technology (IST) for work, leisure and communication. It is underpinned by basic skills in ICT: the use of computers to retrieve, assess, store, produce, present and exchange information, and to communicate and participate in collaborative 
networks via the Internet" [3]. On the other hand Hatlevik and Christophersen. define digital competences as ability to exploit technology in order to use and access information [18]. In addition, according to these authors, digital competences also include the way in which technologies can be used to process, acquire and evaluate collected information, and how information can be created and transmitted using digital tools or media. Digital competences have also been included in the recommendations of the Council of the European Union as one of eight groups of key competences in the process of lifelong learning. In this document, digital competences have been defined as certain, critical and responsible use of digital technologies and interest in them for learning, work and participation in society European Union [19]. In turn, the European Digital Competence Framework for Citizens, referred to as DigComp, describes digital competences and groups them in five areas: information, communication, content creation, security and problem solving. According to this framework, in the modern world, a person with digital competence must move smoothly within these five areas, not just be able to use the functions of digital technologies.

The division of competences into IT and information level competences has also been extended by the level of functional competences. Functional competences are based on IT and information competences, which are foundation for implementing specific actions and achieving benefits through the use of digital technologies. Functional competences refer to eight areas of life, which were determined on the basis of research on areas of activity of Internet users. They included such areas as: work and professional development, relations with loved ones, realization of interests, health, finance, religion and spiritual needs, everyday matters and civic involvement [20].

Digital competence is increasingly the subject of multiple research papers. Digital skills related to the use of ICT are examined and assessed among students [21-24] also at the secondary level [25] or developing these skills among teachers [26,27] or other working [4] in order to create significant educational environments for future citizens. At the same time, it is not stated that the competences at a given level of education are the same-rather, their high level of differentiation is confirmed [18]. It is important to conduct research on already developed digital competences and on methods of modelling these competences.

\section{Materials and Methods}

Presented different approaches to defining digital competences focus on two basic divisions relating to IT and information competences. These two groups of competences were adopted as the basis for the study of digital competences of Polish and Slovak students. A similar division in their digital competence research of Spanish undergraduate students was used by Guzman-Simon et al. An important element of our research is to indicate how students evaluate their digital competences, for whom the digital world is somewhat a natural world, since from the beginning of their lives this world has been well integrated into their reality. On the one hand, it can be assumed that they are brought up in the digital world and naturally shape their digital competences. On the other hand, it should be assumed that there is a great diversity in how they deal with ICT and what they know about it [6]. In addition, development of digital competences is associated with some effort and time. The study seems to be justified in the light of postulates indicating the need for a broader analysis of a group of young people- the most vulnerable to the development of these competences [28].

For the purpose of this study, own research was carried out, which aimed at analysing the perception of digital competences by Polish and Slovak students. The study was divided into three stages. In the first stage of research, based on the available literature, the groups of competences: IT and information were listed (Table 1). The second stage included selection of a research sample, development of a questionnaire, conducting research and statistical preparation of obtained results. Respondents assessed their skills in the area of surveyed competences based on their own opinion. In the third stage of research, groups of skills within the scope of IT and information competences were determined, both for Polish and Slovak students, which in their opinion they can demonstrate. Statistical relationships. 
Table 1. IT and information competences.

\begin{tabular}{|c|c|c|c|}
\hline Variable & IT Competences & Variable & Information Competences \\
\hline $\mathrm{T} 1$ & Write, edit and send text in a text editor & \multirow[b]{2}{*}{$\mathrm{C} 1$} & \multirow{2}{*}{$\begin{array}{c}\text { locating pages with the information } \\
\text { you need }\end{array}$} \\
\hline $\mathrm{T} 2$ & $\begin{array}{l}\text { Verify the text by checking } \\
\text { spelling/dictionaries }\end{array}$ & & \\
\hline T3 & Insert images/symbols in a text editor & $\mathrm{C} 2$ & web browsing \\
\hline $\mathrm{T} 4$ & Insert and edit tables in a text editor & \multirow[b]{2}{*}{$\mathrm{C} 3$} & \multirow{2}{*}{$\begin{array}{l}\text { Finding the specific information you } \\
\text { need on the websites of government } \\
\text { agencies }\end{array}$} \\
\hline $\mathrm{T} 5$ & $\begin{array}{c}\text { Use drawing/graphics applications such as } \\
\text { Power Point }\end{array}$ & & \\
\hline T6 & Move files/folder on the computer & \multirow{2}{*}{$\mathrm{C} 4$} & \multirow{2}{*}{$\begin{array}{l}\text { searching websites in a language } \\
\text { other than Polish }\end{array}$} \\
\hline $\mathrm{T} 7$ & Move files/folder on the smartphone & & \\
\hline $\mathrm{T} 8$ & Move files/folder between devices & \multirow{2}{*}{ C5 } & \multirow{2}{*}{$\begin{array}{l}\text { selection of the right information } \\
\text { from the Internet }\end{array}$} \\
\hline T9 & Use copy tools & & \\
\hline $\mathrm{T} 10$ & Use cutting tools & \multirow{2}{*}{ C6 } & \multirow{2}{*}{$\begin{array}{l}\text { organized file organization on your } \\
\text { computer }\end{array}$} \\
\hline T11 & using the basic functions of spreadsheet & & \\
\hline $\mathrm{T} 12$ & compressing files & \multirow[b]{2}{*}{ C7 } & \multirow{2}{*}{$\begin{array}{l}\text { Organize the information found by } \\
\text { e.g., placing them in lists and tables }\end{array}$} \\
\hline T13 & $\begin{array}{l}\text { Connect and install new devices, e.g., } \\
\text { printer, scanner, etc.? }\end{array}$ & & \\
\hline T14 & Install the program on your computer & \multirow{3}{*}{$\mathrm{C} 8$} & \multirow{3}{*}{$\begin{array}{l}\text { Assess the quality of information } \\
\text { that can be found on the Internet, } \\
\text { for example, whether it is old, } \\
\text { biased or unreliable }\end{array}$} \\
\hline $\mathrm{T} 15$ & $\begin{array}{l}\text { Search for and install a smartphone } \\
\text { program/application }\end{array}$ & & \\
\hline T16 & Uninstall the program on your computer & & \\
\hline T17 & $\begin{array}{l}\text { Uninstall the program/application yourself } \\
\text { on your smartphone }\end{array}$ & \multirow[t]{2}{*}{ C9 } & \multirow{2}{*}{$\begin{array}{c}\text { Assess the security level of } \\
\text { publishing information on the } \\
\text { Internet, for example on Facebook, }\end{array}$} \\
\hline T18 & Programming in a specialist language & & \\
\hline T19 & $\begin{array}{c}\text { Use internet search engines (e.g., Google, } \\
\text { Yahoo etc.) }\end{array}$ & $\mathrm{C} 10$ & $\begin{array}{l}\text { entering information using a } \\
\text { template on the web }\end{array}$ \\
\hline $\mathrm{T} 20$ & transferring data from a spreadsheet & $\mathrm{C} 11$ & Read and/or comment on the blog \\
\hline $\mathrm{T} 21$ & Set up/create private email address & & \\
\hline $\mathrm{T} 22$ & Send and receive e-mail & & \\
\hline $\mathrm{T} 23$ & Send an email with attachments & & \\
\hline $\mathrm{T} 24$ & using e-mail/calendar systems & & \\
\hline $\mathrm{T} 25$ & using file-sharing programs (P2P) & & \\
\hline $\mathrm{T} 26$ & creating websites & & \\
\hline $\mathrm{T} 27$ & $\begin{array}{l}\text { Transfer photos from a digital camera to a } \\
\text { computer }\end{array}$ & & \\
\hline $\mathrm{T} 28$ & $\begin{array}{l}\text { Transfer photos from a smartphone to a } \\
\text { computer }\end{array}$ & & \\
\hline $\mathrm{T} 29$ & Make calls via the Internet & & \\
\hline $\mathrm{T} 30$ & creating an electronic signature & & \\
\hline $\mathrm{T} 31$ & $\begin{array}{l}\text { Send/receive SMS/MMS from a mobile } \\
\text { phone }\end{array}$ & & \\
\hline $\mathrm{T} 32$ & $\begin{array}{l}\text { Connect to the Internet using a mobile } \\
\text { phone }\end{array}$ & & \\
\hline T33 & Order and buy tickets online & & \\
\hline
\end{tabular}


Table 1. Cont.

\begin{tabular}{|c|c|c|c|}
\hline Variable & IT Competences & Variable & Information Competences \\
\hline T34 & Buy and sell goods via native websites & & \\
\hline T35 & $\begin{array}{l}\text { making commercial transactions using } \\
\text { languages other than native }\end{array}$ & & \\
\hline T36 & Use IP telephony or Skype & & \\
\hline T37 & Using an electronic signature & & \\
\hline $\mathrm{T} 38$ & $\begin{array}{l}\text { Participate in online communities, e.g., } \\
\text { Facebook or Instagram }\end{array}$ & & \\
\hline
\end{tabular}

Source: Own processing.

For statistical analysis, we used the Statistica 12 programming software, which we chose as a suitable tool for creating statistical models and data analysis. This program is also used in the creation of graphs and their subsequent analysis. During the clustering process, we chose Ward's method and the degree of similarity of the investigated objects was determined using the Euclidean distance.

A prerequisite for performing a cluster analysis is the testing of statistical significances depending on the individual variables at the significance level of $5 \%(\alpha=5 \%)$. The starting point for the analysis was the construction of a correlation matrix that contains Spearman correlation coefficients. In compiling this matrix, we tried to eliminate the problem of high dependence between variables, which could affect the results of the classification. To partially solve the problem, we used the main components method, which transforms the input indicators into new variables. The cut-off level-indicating the number of groups - was set arbitrarily on the basis of graphical analysis and marked with a dashed line. A given group includes the answers with the greatest similarity in terms of frequency and structure of occurrence. Due to the presence of an interval scale in the research questionnaire, the U-Mann-Whitney test was used for group comparisons (e.g., Polish and Slovak students), which is treated as an equivalent of the t-Student's test for weaker scales.

\section{Results}

The study involved 343 Polish and Slovak students, including 172 from Poland and 171 from Slovakia. The survey was conducted in October-December 2018. Students participating in the study were students of both engineering and bachelor studies. They were full-time and part-time first and second cycle students. The survey was conducted directly using survey questionnaires. Reliability of the questionnaire was verified using Alfa-Cronbach $(\alpha=0.973)$.

Division into two groups of competences seems to be clear (Figure 1). The first concerns programming in a specialist language, using file-sharing programs (P2P), creating websites and an electronic signature, using that signature and making commercial transactions using languages other than Polish. A deeper division would isolate, at most, programming in a specialist language from this group. Other IT competences are basically grouped, and further division would distinguish two groups.

In the case of Slovak students, the division into two groups reaches a distance of "60" (Figure 2). In the first group, transactions in a foreign language were not indicated, but IT competences such as using e-mail/calendar systems, transferring data from a spreadsheet, using the basic functions of this spreadsheet and compressing files were included. In practice, in the case of Slovak students, the division into three groups of IT competences seems to be more justified. 


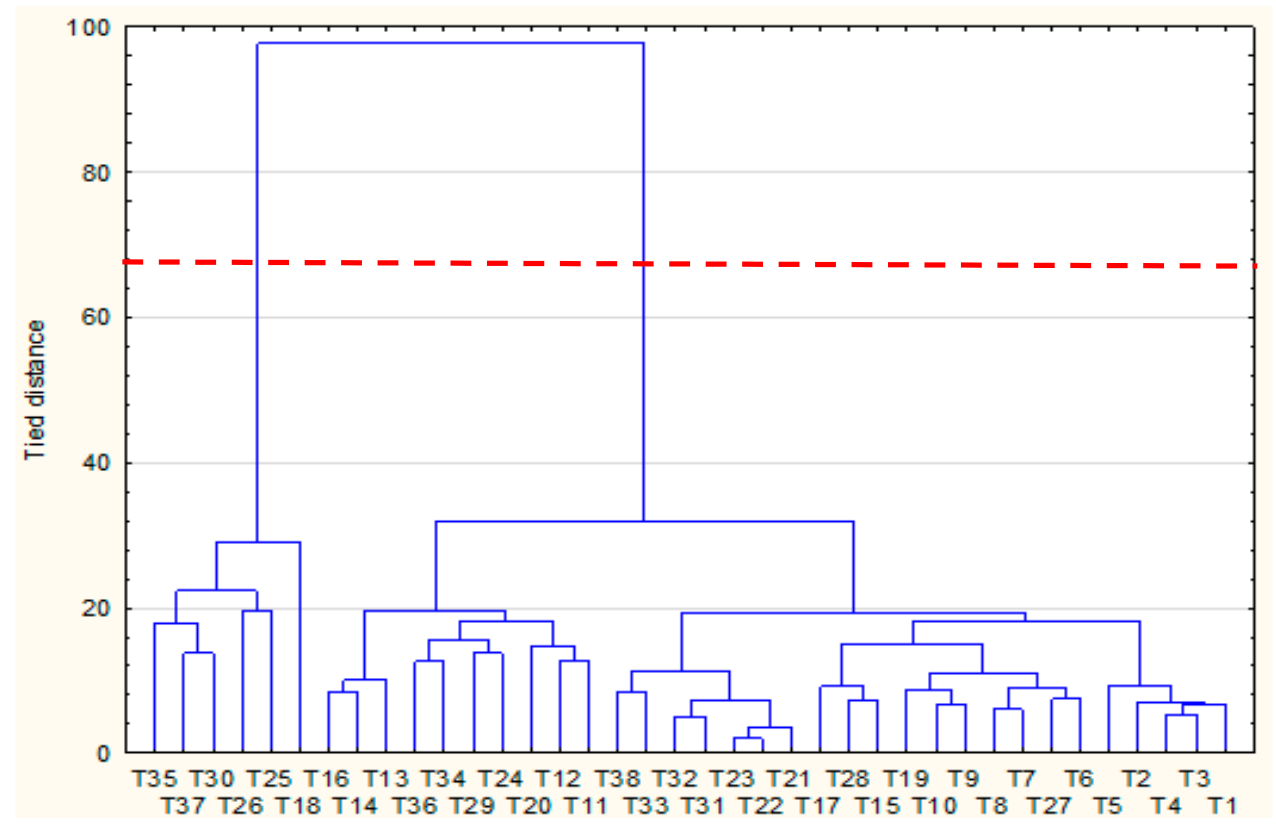

Figure 1. Cluster analysis using Euclidean distance (Ward method) for digital and IT competences-students in Poland. Source: own elaboration.

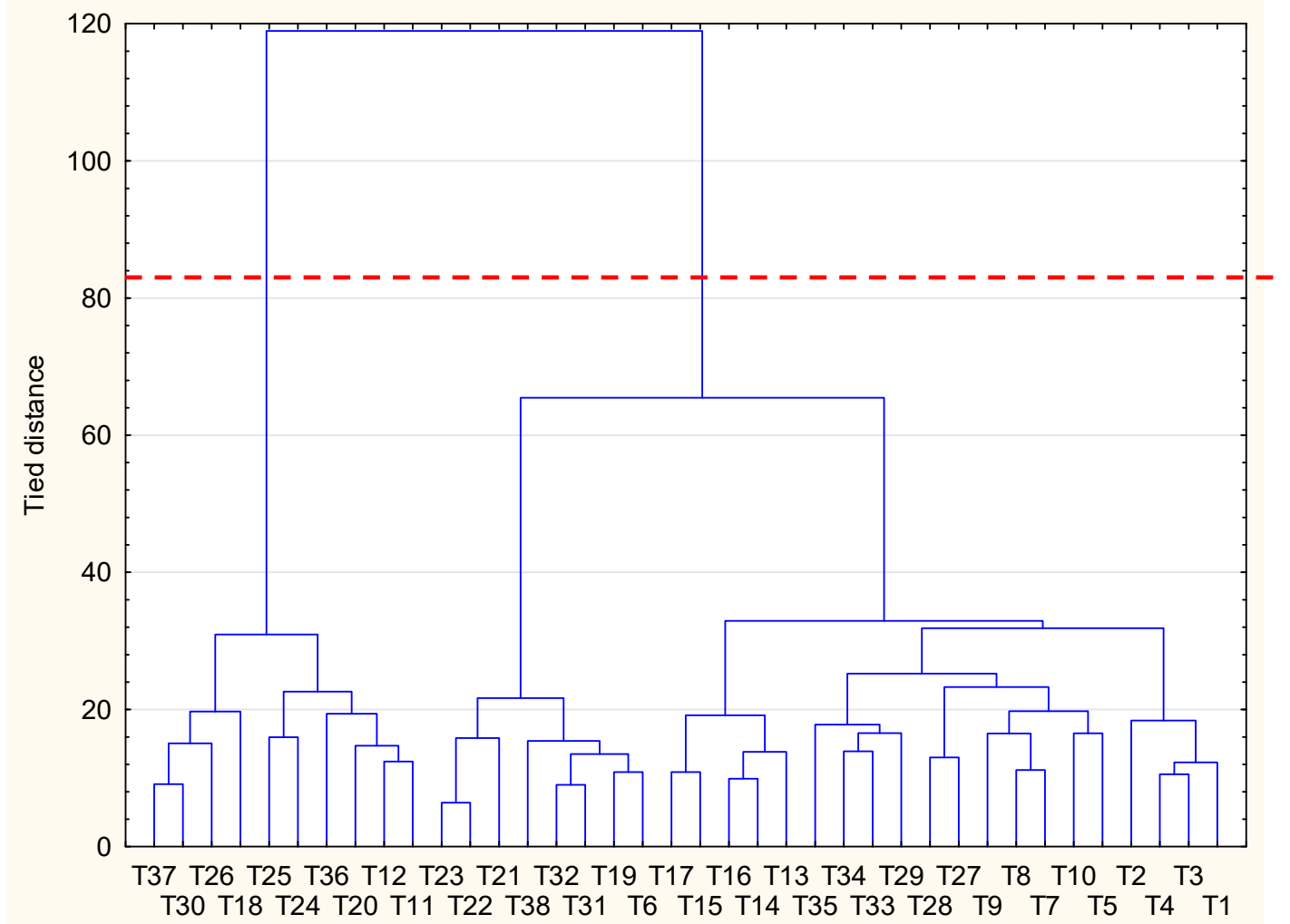

Figure 2. Cluster analysis using Euclidean distance (Ward method) for digital and IT competences-students in Slovakia. Source: own elaboration.

In the case of digital information competences, differences in the approach of respondents from both countries are much clearer (Figure 3). In Slovakia, one group includes web browsing and locating pages with the information you need, organized file organization on your computer and selection of the right information from the Internet. In the case of Poland, these competences are also closely 
related, but they occur in a much broader group. In turn, here we can distinguish a two-element group containing only searching websites in a language other than Polish and entering information using a template on the web.
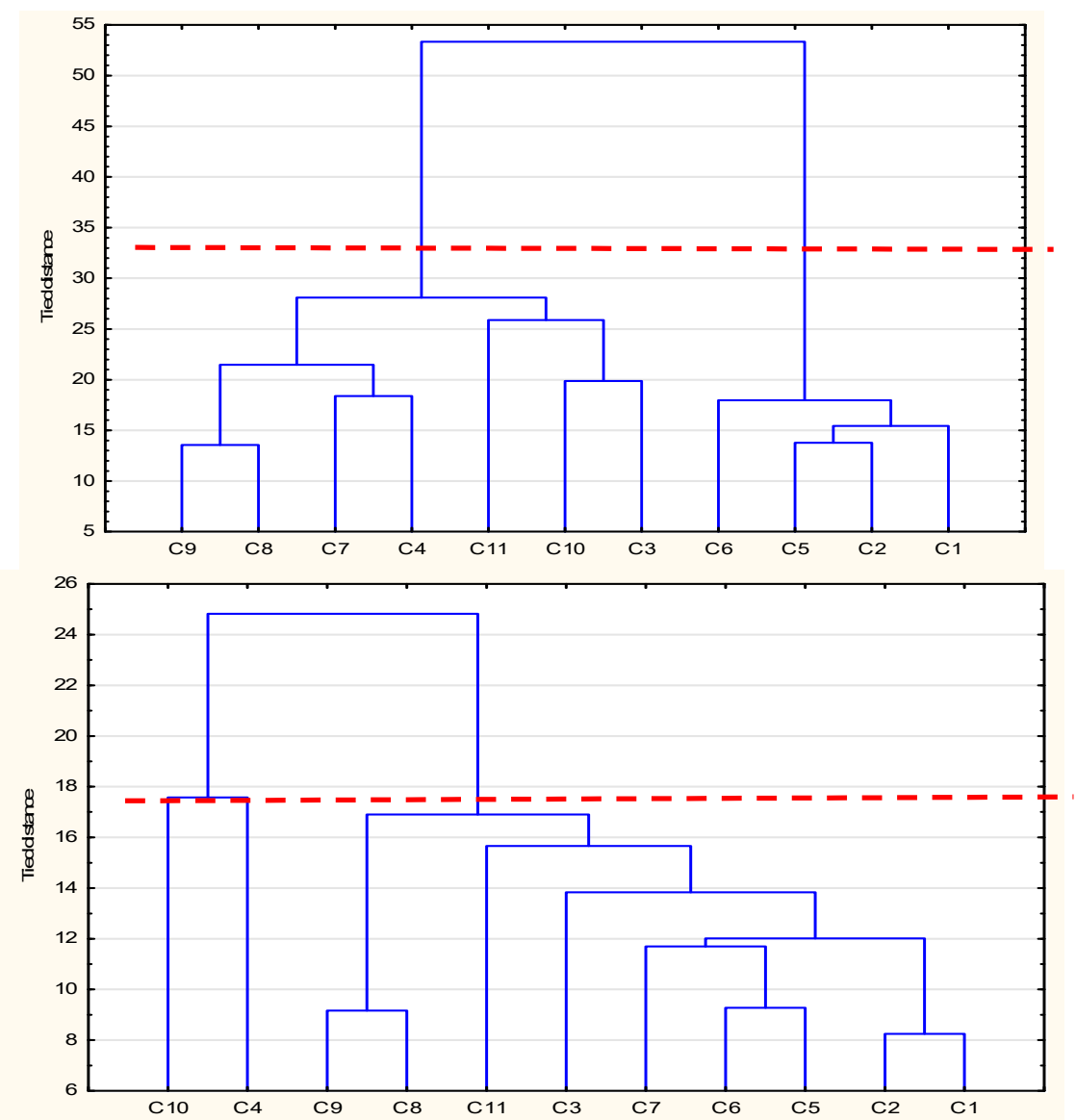

Figure 3. Cluster analysis using Euclidean distance (Ward method) for digital and IT competences—students in Poland and Slovakia. Source: own elaboration.

In the case of competences, Polish students clearly have stronger relationships. As much as $89.2 \%$ of the correlations between competences are statistically significant and positive correlations. For Slovak students, this only applies to $69.8 \%$ of them, while an additional $8(1.1 \%)$ are statistically significant negative correlations between competences.

Results of the U-Mann-Whitney test clearly show that in all cases (except for locating websites containing important information) Polish students rate their competences higher than their Slovak counterparts (Table 2).

In general, the assessment of the level of digital competence of Polish students is not only higher but also less diverse. According to the PISA research, Polish students also demonstrate higher competences than Slovak ones in all surveyed areas, and this difference is significant [29]. These results, although consistent with other reports, raise some doubts. Therefore, the data held, although determined on the same scale, was normalized. The obtained ratings were once again subjected to the testing procedure. The hypothesis: 'equal/unequal level of assessment of a given competence between students from Poland and Slovakia' was verified. 
Table 2. Mann-Whitney coefficient values for competences assigned to students from Poland and Slovakia.

\begin{tabular}{|c|c|c|c|c|c|c|c|c|c|}
\hline \multirow{2}{*}{ Variable } & \multicolumn{2}{|c|}{ Raw Data } & \multicolumn{2}{|c|}{$\begin{array}{c}\text { After } \\
\text { Normalization }\end{array}$} & \multirow{2}{*}{ Variable } & \multicolumn{2}{|c|}{ Raw Data } & \multicolumn{2}{|c|}{$\begin{array}{c}\text { After } \\
\text { Normalization }\end{array}$} \\
\hline & Z & $P$ & $\mathrm{Z}$ & $P$ & & Z & $P$ & $\mathbf{Z}$ & $P$ \\
\hline $\mathrm{T} 1$ & 10.838 & 0.000 & -1.179 & 0.238 & T26 & 10.302 & 0.000 & 1.423 & 0.155 \\
\hline $\mathrm{T} 2$ & 11.589 & 0.000 & -0.499 & 0.618 & T27 & 11.112 & 0.000 & 3.582 & 0.000 \\
\hline T3 & 11.837 & 0.000 & 0.094 & 0.925 & $\mathrm{~T} 28$ & 10.56 & 0.000 & 1.883 & 0.060 \\
\hline $\mathrm{T} 4$ & 11.658 & 0.000 & 0.415 & 0.678 & T29 & 8.798 & 0.000 & -2.381 & 0.017 \\
\hline T5 & 9.984 & 0.000 & -2.154 & 0.031 & T30 & 9.819 & 0.000 & -0.060 & 0.952 \\
\hline T6 & 4.700 & 0.000 & -5.497 & 0.000 & T31 & 6.746 & 0.000 & 1.969 & 0.049 \\
\hline $\mathrm{T} 7$ & 7.833 & 0.000 & 0.223 & 0.823 & $\mathrm{~T} 32$ & 3.915 & 0.000 & 1.046 & 0.295 \\
\hline T8 & 9.497 & 0.000 & 2.976 & 0.003 & T33 & 9.222 & 0.000 & 1.198 & 0.231 \\
\hline T9 & 9.546 & 0.000 & 2.579 & 0.010 & T34 & 7.125 & 0.000 & 0.117 & 0.907 \\
\hline T10 & 10.776 & 0.000 & 1.028 & 0.304 & T35 & 6.241 & 0.000 & -2.351 & 0.019 \\
\hline T11 & 12.864 & 0.000 & 1.295 & 0.195 & T36 & 11.663 & 0.000 & 2.744 & 0.006 \\
\hline T12 & 11.877 & 0.000 & 5.169 & 0.000 & T37 & 9.48 & 0.000 & 2.071 & 0.038 \\
\hline $\mathrm{T} 13$ & 11.128 & 0.000 & 0.861 & 0.389 & T38 & 5.402 & 0.000 & 0.947 & 0.344 \\
\hline T14 & 11.247 & 0.000 & 1.248 & 0.212 & $\mathrm{C} 1$ & 1.446 & 0.148 & -0.055 & 0.956 \\
\hline T15 & 10.197 & 0.000 & -2.422 & 0.015 & C2 & 5.262 & 0.000 & -4.290 & 0.000 \\
\hline T16 & 11.777 & 0.000 & 0.963 & 0.336 & C3 & 5.506 & 0.000 & -9.140 & 0.000 \\
\hline T17 & 10.506 & 0.000 & -0.750 & 0.453 & C4 & 8.752 & 0.000 & 2.328 & 0.020 \\
\hline T18 & 3.309 & 0.001 & -1.418 & 0.156 & C5 & 11.381 & 0.000 & 1.071 & 0.284 \\
\hline T19 & 4.372 & 0.000 & -6.386 & 0.000 & C6 & 11.028 & 0.000 & 1.733 & 0.083 \\
\hline T20 & 10.892 & 0.000 & -7.398 & 0.000 & C7 & 10.291 & 0.000 & 2.806 & 0.005 \\
\hline T21 & 10.259 & 0.000 & 0.120 & 0.904 & C8 & 11.788 & 0.000 & 3.775 & 0.000 \\
\hline T22 & 8.167 & 0.000 & 3.105 & 0.002 & C9 & 10.709 & 0.000 & 1.151 & 0.250 \\
\hline T23 & 9.204 & 0.000 & 1.692 & 0.091 & $\mathrm{C} 10$ & 7.107 & 0.000 & -4.852 & 0.000 \\
\hline T24 & 11.016 & 0.000 & -0.612 & 0.541 & C11 & 11.598 & 0.000 & 2.557 & 0.011 \\
\hline T25 & 9.33 & 0.000 & 1.512 & 0.130 & & & & & \\
\hline
\end{tabular}

Source: Own processing.

Out of 49 examined competences, 32 were rated higher for students from Poland, including 12 significantly higher. In turn, for Slovak students 17 competences were rated higher, including 10 higher than for Polish students. Thanks to the tool used, we received information about the advantage of assessing a given competence in relation to others. Moreover, possible disturbances resulting from customs, cultural behavior, 'false' modesty have been eliminated thanks to normalization. It turns out that while in the case of IT competences the most of Polish students is clear ( 25 out of 38, including 9 important ones, in the case of Information competences we are dealing with almost equilibrium, and certainly it concerns the number of significant advantages (Figure 4).

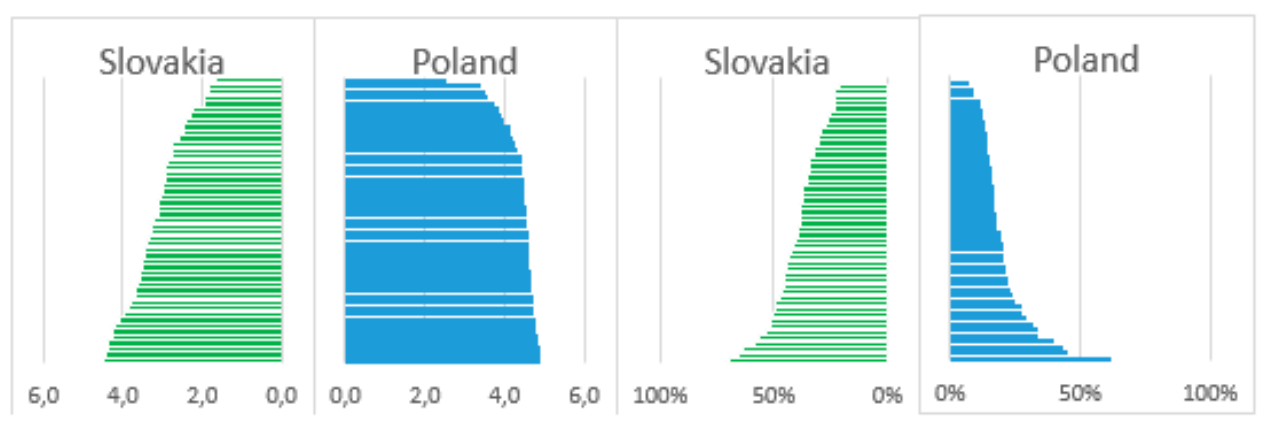

Figure 4. Average grades for students from Poland and Slovakia as well as average grading. Source: own elaboration.

It turns out that diversity of competences of Slovak students is significantly higher than that of Polish students $(\mathrm{F}=2.648 ; p<0.001)$. Moreover, in the case of student competence assessments in Poland, a statistically significant positive correlation is observed between the size of grades and their 
differentiation ( $\left.\mathrm{r}_{\mathrm{xy}}=-0.986 ; p<0.001\right)$, in contrast to Slovak students $\left(\mathrm{r}_{\mathrm{xy}}=0.840 ; p<0.001\right)$. If we assumed that a grade above 2.5 was acceptable and satisfactory, at least $3,20 \%$ of competences in Slovakia would be assessed unacceptably and 39 unsatisfactory. In Poland, only programming in a specialized language would receive an unsatisfactory but acceptable assessment (2.51).

\section{Discussion}

The proposed assessment of digital competences is one of the approaches that can be taken as a voice in the extensive discussion on these assessments and the complications associated with it. Research on the perception of the diversity of digital competences of various social and professional groups is important not only for the development of a strategy for strengthening digital futures in individual regions [30] but also for larger areas. Having digital competences supports distance education and opens up opportunities for further education [31].

The conducted research did not take into account the factors influencing the level of digital competences, as was the case with the research by Hatlevik and Christophersen [18]. Nevertheless, this study also found differences in the digital competences of learners from different schools. This means that the competences at a given level of education are not the same, which rather confirms their level of differentiation and corresponds to the results obtained by other researchers [17]. The presented research also correlates with the PISA research, according to which Polish students show higher than Slovak competences in all the analyzed areas, and this difference is significant [32].

An important element in creating digital competences of students is the analysis of the relationship between educational programs and the level of competences of learners, which has not been taken into account in this study, and, as the papers indicate $[10,23,27,33]$ obtaining an answer regarding these relationships will allow for the creation of appropriate work and education environments.

Our research shows that students cope better with basic tasks describing digital competences than with more difficult tasks, where the level of their competences is rather low [34]. The obtained results are important not only at the level of shaping an appropriate education strategy, but also at the stage of finding a suitable job $[35,36]$ by people graduating from schools and universities. In the modern world, digital competences affect the quality of life of an individual and entire organizations, which is why their constant monitoring, classification and evaluation is a process included in the development of our society.

\section{Conclusions}

Research presented in the work shows how Polish and Slovak students perceive their digital competences. Such results do not imply how actual skills really look like because at this stage of research they have not been verified. These studies primarily show similarities and differences in the perception of skills between groups of questioned students and can indicate those groups of competences that are more developed or needed in a given environment. Results of these studies may be important for creating new educational environments for future citizens [10].

Research results showed that assessment of the level of digital competences of Polish students is not only higher but also less diverse (Figures 1 and 2). In addition, it was pointed out that IT competences of Polish students can be divided into two groups and Slovak ones into three groups. The first group for Polish and Slovak students is almost the same-In Poland it is a bit broader but contains (apart from buying and selling goods via websites in languages other than native) all variables indicated in Slovakia. In both cases, variables listed in the top ten are furthest from the mentioned group. The other grouping elements, however, are much more diverse. In the case of digital information competences, clearer differences in the view of respondents from both countries were observed (Figure 3).

The way students perceive their competences can be important when looking for a job, building a career, creating relationships and overall functioning in society. In addition, research results can be 
useful for those in charge of education who are developing a new learning framework at every level of education to improve the competences of students.

Obtained results of the research cannot be generalized to other groups of students because it carries some risk resulting from limitation of the research. This study does not identify elements that are relevant to shaping competences, to what extent participation in classes, level of studies, their type and field of study have an impact on the perception of digital competences. This also applies to the status of origin or the fact that students undertake work during their studies.

Nevertheless, presented results should form the basis for further discussion on the development and direction of shaping digital competences. The significance of ICT is constantly growing, therefore research related to digital competences can contribute to their better development, which is important.

Author Contributions: Conceptualization, M.S., Z.H., K.S. and L.B.; methodology, Z.H.; software, M.S.; formal analysis, K.S., Z.H. and L.B., methodology, M.S.; data preparation, K.S.; writing-original draft preparation, Z.H. and L.B.; writing-review and editing, M.S., Z.H. and K.S., L.B.; visualization, Z.H. and M.S. All authors have read and agreed to the published version of the manuscript.

Funding: This research was funded by Kultúrna a edukacná grantová agentúra MŠVVaŠ SR, grant number KEGA 026EU4/2018, KEGA 032EU-4/2020, VEGA 1/0240/20.

Conflicts of Interest: The authors declare no conflict of interest.

\section{References}

1. Ayale-Perez, T.; Joo-Nagata, J. The digital culture of students of pedagogy specialising in the humanities in Santiago de Chile. Comput. Educ. 2019, 133, 1-12. [CrossRef]

2. Rippa, P.; Secundo, G. Digital academic entrepreneurship: The potential of digital technologies on academic entrepreneurship. Technol. Forecast. Soc. Chang. 2019, 146, 900-911. [CrossRef]

3. Ferrari, A. Digital Competence in Practice: An Analysis of Framework; Publications Office of The European Union: Luxembourg, 2012; ISBN 978-92-79-25093-4.

4. Murawski, M.; Bick, M. Digital competences of the workforce-A research topic? Bus. Process Manag. J. 2017, 23, 721-734. [CrossRef]

5. Eshet-Alkalai, Y. Digital literacy. A conceptual framework for survival skills in the digital era. J. Educ. Multimed Hypermedia 2004, 13, 93-106.

6. Hargittai, E. Digital $\mathrm{Na}(\mathrm{T})$ Ives? Variation in internet skills and uses among members of the 'Net Generation'. Socio. Inq. 2010, 80, 92-113. [CrossRef]

7. Van Deursen, A.J.A.M.; Van Dijk, J.A.G.M.; Peters, O. Rethinking internet skills. The contribution of gender, age, education, internet experience, and hours online to medium- and content-related internet skills. Poetics 2011, 39, 125-144. [CrossRef]

8. PérezMateo, M.; Romero, M.; Romeu, T. Collaborative construction of a project as a methodology for acquiring digital competences. Media Educ. Res. J. 2014, 15-23. [CrossRef]

9. Rambouseka, V.; Štípeka, J.; Vaňková, P. Contents of digital literacy from the perspective of teachers and pupils. Procedia Soc. Behav. Sci. 2016, 217, 354-362. [CrossRef]

10. Svenssona, M.; Baelob, R. Teacher students' perceptions of their digital competence. Procedia Soc. Behav. Sci. 2015, 180, 1527-1534. [CrossRef]

11. Sandberg, J. Understanding human competence at work: An interpretative approach. Acad. Manag. J. 2010, 43, 9-25.

12. Rizal, R.; Setiawan, W.; Rusdiana, D. Digital literacy of preservice science teacher. J. Phys. Conf. Ser. 2019. [CrossRef]

13. Vázquez-Cano, E.; León Urrutia, M.; Parra-González, M.E.; López Meneses, E. Analysis of interpersonal competences in the use of ICT in the Spanish University context. Sustainability 2020, 12, 476. [CrossRef]

14. Somyürek, S.; Karabulut Coskun, B. Digital competence: Is it an innate talent of the new generation or an ability that must be developed? Br. J. Educ. Technol. 2013, 44, 163-166. [CrossRef]

15. Janssen, J.; Stoyanov, S.; Ferrari, A.; Punie, Y.; Pannekeet, K.; Sloep, P. Experts' views on digital competence: Commonalities and differences. Comput. Educ. 2013, 68, 473-481. [CrossRef] 
16. Holtkamp, P.; Pawlowski, J.M. A competence-based view on the global software development process. J. Univers. Comput. Sci. 2013, 21, 1385-1404.

17. Hatlevik, O.E.; Bjöork Guðmundsdóttir, G.; Loi, M. Digital diversity among upper secondary students: A multilevel analysis of the relationship between cultural capital, self-efficacy, strategic use of information and digital competence. Comput. Educ. 2015, 81, 345-353. [CrossRef]

18. Hatlevik, O.E.; Christophersen, K.A. Digital competence at the beginning of upper secondary school: Identifying Factors explaining digital inclusion. Comput. Educ. 2013, 63, 240-247. [CrossRef]

19. Ala-Mutka, K. Mapping digital competence: Towards a conceptual understanding. In JRC Technical Note; Institute of Prospective Technological Studies, European Commission: Seville, Spain, 2011.

20. Jasiewicz, J.; Filiciak, M.; Mierzecka, A.; Śliwowski, K.; Klimczuk, A.; Kisilowska, M.; Tarkowski, A.; Zadrożny, J. Ramowy katalog kompetencji cyfrowych, centrum cyfrowe projekt. Warszawa 2015. [CrossRef]

21. Calvani, A.; Fini, A.; Ranieri, M.; Picci, P. Are young generations in secondary school digitally competent? A study on Italian teenagers. Comput. Educ. 2012, 58, 797-807. [CrossRef]

22. Guzman-Simon, F.; García-Jimenez, E.; Lopez-Cobo, I. Undergraduate students' perspectives on digital competence and academic literacy in a Spanish University. Comput. Hum. Behav. 2017, 74, 196-204. [CrossRef]

23. García-Martín, J.; García-Sanchez, J.N. Pre-service teachers' perceptions of the competence dimensions of digital literacy and of psychological and educational measures. Comput. Educ. 2017, 107, 54-67. [CrossRef]

24. Sharimana, T.P.N.T.; Razakb, N.A.; Noora, N.F.M. Digital literacy competence for academic needs: An analysis of malaysian students in three Universities. Procedia Soc. Behav. Sci. 2012, 69, 1489-1496. [CrossRef]

25. Morales, H.O.; Espinosa, A.H.; Duque, R.L.; Barrera, G.E.; Casas, S.V. Mapping digital competences of modern languages students. Rev. Acad. Y Virtualidad 2016, 9, 89-104.

26. Claro, M.; Preiss, D.; San Martín, E.; Jara, I.; Hinostroza, J.E.; Valenzuela, S.; Cortes, F.; Nussbaum, M. Teaching in a Digital Environment (TIDE): Defining and measuring teachers' capacity to develop students' digital information and communication skills. Comput. Educ. 2018, 121, 162-174. [CrossRef]

27. Instefjord, E.J.; Munthe, E. Educating digitally competent teachers: A study of integration of professional digital competence in teacher education. Teach. Teach. Educ. 2017, 67, 37-45. [CrossRef]

28. Hazar, E. A comparison between European digital competence framework and the Turkish ict curriculum. Univers. J. Educ. Res. 2019, 7, 954-962. [CrossRef]

29. Calvani, A.; Cartelli, A.; Fini, A.; Ranieri, M. Models and instruments for assessing digital competence at school. J. e-Learn. Knowl. Soc. 2008, 4, 183-193.

30. Alam, K.; Erdiaw-Kwasie, M.O.; Shahiduzzaman, M.; Ryan, B. Assessing regional digital competence: Digital futures and strategic planning implications. J. Rural Stud. 2008, 60, 60-69. [CrossRef]

31. Castaño-Muñoz, J.; Kreijns, K.; Kalz, M.; Punie, Y. Does digital competence and occupational setting influence MOOC participation? Evidence from a cross-course survey. J. Comput. High. Educ. 2017, 29, $28-46$. [CrossRef]

32. OECD. PISA 2018 Results (Volume I): What Students Know and Can Do, PISA; OECD Publishing: Paris, France, 2019. [CrossRef]

33. Tømtea, C.; Enochssonb, A.-B.; Buskqvistc, U.; Kårsteina, A. Educating online student teachers to master professional digital competence: The TPACK-framework goes online. Comput. Educ. 2015, 84, $26-35$. [CrossRef]

34. Crawford-Visbala, J.L.; Crawford-Tiradob, L.; Ortiz-Záccaroc, Z.Z.; Abalod, F. Assessment of digital competences in communication students across four Latin American Universities. Educ. Knowl. Soc. 2020, $21,20$.

35. Buchi, G.; Cugno, M.; Castagnoli, R. Smart factory performance and Industry 4.0. Technol. Forecast. Soc. Chang. 2020, 150, 119790. [CrossRef]

36. Periáñez-Cañadillas, I.; Charterina, J.; Pando-García, J. Assessing the relevance of digital competences on business graduates' suitability for a job. Ind. Commer. Train. 2019, 51, 139-151. [CrossRef]

(C) 2020 by the authors. Licensee MDPI, Basel, Switzerland. This article is an open access article distributed under the terms and conditions of the Creative Commons Attribution (CC BY) license (http://creativecommons.org/licenses/by/4.0/). 